\title{
КОСТЯНТИН ГЕОРГІЙОВИЧ БРЕСЛАВЕЦЬ (1941-2012)
}

\author{
Анатолій Шушківський \\ Інститут енциклопедичних досліджень НАН Украйни, \\ Київ, Украӥна
}

Персонологічне дослідження присвячено авторові статей та координатору «Енциклопедії Сучасної України», кандидату фізико-математичних наук Костянтину Бреславцю.

Ключові слова: Костянтин Бреславець, «Енциклопедія Сучасної України», Харківський фізико-технічний інститут, Харків.

Харківський фахівець з фізико-технічних наук, багаторічний співробітник Національного наукового центру «Харківський фізико-технічний інститут» НАН України (ХФТІ) Костянтин Бреславець координував від своєї установи укладання «Енциклопедії Сучасної України» (ЕСУ), починаючи з першого тому. Нині за його авторством в ЕСУ опубліковано лише 4 статті (у другому томі - про подружжя Анатолія та Галину Березіних, у 3-му - про Фелікса Бусла, у шістнадцятому - про Віктора Лебедєва), а також заплановано розміщення в наступних томах незначної кількості статей (наприклад, Галину Полякову, Липу Розенцвейга), однак цей доробок - лише незначна частина того внеску, який він зробив для творення національної енциклопедії.

У 1998-99 роках К. Бреславець здійснив роботу зі складання переліку гасел науковців ХФТІ, про яких варто розмістити окремі статті в ЕСУ. Йому довелося докласти значних зусиль, щоб відслідкувати фактично всіх визначних учених (переважно докторів, а подекуди й кандидатів наук), які в різний час (зокрема і довоєнний; лише кілька років чи значний період) працювали в ХФТІ - одному з найстаріших і найбільших центрів фізичної науки в Україні. Надалі цей список він постійно поповнював прізвищами тих, хто захистив докторські дисертації протягом року або перейшов працювати до ХФТІ з інших наукових установ, ВНЗів чи приїхав з інших країн. Костянтин Геор- 
гійович на адресу Координаційного бюро ЕСУ НАН України (пізніше - Інституту енциклопедичних досліджень НАН України) надіслав понад 180 біографічних довідок, до написання яких залучив Ю. М. Ранюка, А. М. Довбню, I. М. Неклюдова, С. В. Пелетминського, В. М. Ажажу, М. Ф. Шульгу, Ю. Л. Болотіна, О. М. Єгорова, Р. П. Слабоспицького, В. Ф. Зеленського та ін. Низку анкет з біографіями вчених і характеристикою їхнього наукового доробку склав особисто на основі архівних даних або записав зі слів анкетованих.

Упродовж понад десяти років постійно доповнював надіслану раніше інформацію (наприклад, коли відходили люди старшого покоління, а живі отримували звання, премії, переходили на іншу посаду або на інше місце роботи, оновлював перелік опублікованих праць), вичитував статті безпосередньо перед верстанням чергового тому. До Костянтина Георгійовича можна було звернутися стосовно фізиків, які працювали в інших харківських науково-дослідних осередках, а також за порадою щодо кандидатур, яким можна замовити загальну статтю фізико-технічного профілю.

Костянтин Бреславець народився 16 січня 1941 року в Харкові в сім"і механіка заводу «Електромашина» Георгія Прокоповича та бухгалтера трамвайно-тролейбусного депо Антоніни Петрівни (дівоче прізвище - Плиско). Ішла друга світова війна, і згодом після нападу нацистської Німеччини на СРСР батька мобілізували на фронт у танкові війська. Провоювавши 4 роки, він у червні 1945-го загинув. Мама також померла в молодому віці, залишивши малого Костю круглим сиротою. Гідному вихованню, незважаючи на воєнні та повоєнні матеріальні труднощі, Костянтин Георгійович завдячує своїм дідусеві та бабусі по маминій лінії. Вони змогли забезпечити його батьківською любов’ю, вказати вірний шлях у житті. У подальшому він буде згадувати про це неодноразово і з вдячністю.

Після закінчення у 1958 році загальноосвітньої школи зі срібною медаллю 17-річний Костянтин вступив на вечірнє відділення фізико-математичного факультету Харківського державного університету імені О. Горького (нині імені В. Каразіна) та водночас розпочав працювати набірником в обласній друкарні. За життя він був енергійною людиною, йому вдавалося поєднувати працю з навчанням, потім наукову діяльність із сімейними справами, зокрема і з вихованням дітей. Костянтину Георгійовичу завжди вистачало часу й на відпочинок, який зазвичай полюбляв проводити активно, і на заняття різноманітними улюбленими справами. У студентські роки захопився туризмом, особливо гірським, разом із друзями побував у багатьох куточках Кавказу та Алтаю. Іноді наукова діяльність на деякий період відривала його від рідних, але згодом він намагався це надолужити з подвійною віддачею. До дітей у нього було особливе ставлення. Рано втративши своїх батьків, Костянтин Георгійович огорнув сина та доньку якнайпалкішою любов'ю, немовби прагнув віддати їм часточку своєї душі. Читав їм книжки, розповідав казки, які сам придумав; улітку ходив з ними в походи харківськими околицями з обов'язковим розведенням багаття, у якому пекли картоплю; взимку каталися в лісі на лижах. 
Костянтин Георгійович зібрав удома велику бібліотеку, в якій, окрім фахових книг з фізико-технічної проблематики, історії науки та техніки (присвячені харківським науково-дослідним установам, про життя та діяльність Абрама Йоффе, Бориса Лазарева, Олександра Усикова, Віктора Іванова, Володимира Толока, Миколи Хижняка тощо), є багато книг з історії України. К. Бреславець сповідував українські цінності, дуже пишався тим, що він не просто українець, a $\in$ ним у сьомому поколінні; що народився, виріс і мешкав в Україні; пишався iï славетним минулим, культурою, природними багатствами, науковим потенціалом; бажав їй добробуту та процвітання; вірив у те, що в нашої держави $\epsilon$ всі можливості, щоб бути однією з найбільш розвинутих в Європі.

1960 року, продовжуючи навчання у ВНЗі, перейшов на роботу до Інституту радіофізики та електроніки АН УРСР на посаду техніка-конструктора. Імовірно, саме в стінах цього закладу він по-справжньому усвідомив своє призначення та отримав перший цінний науковий досвід. У грудні наступного року разом з групою однокурсників став співробітником Харківського фізико-технічного інституту АН УРСР (ХФТІ; від 1993 - сучасна назва), який не залишав до виходу в 2011 році на наукову пенсію за станом здоров’я. Від 1965 до 1983 року К. Бреславець обіймав посаду молодшого наукового співробітника лабораторії молекулярної фізики (№ 15-20) та брав безпосередню участь у наукових дослідженнях, які стосувалися фізики та техніки низьких температур, кріовакуумної адсорбції газів і парів низькокиплячих рідин (гелій, водень, неон, азот і їхні суміші) на адсорбентах різного походження та пористості (синтетичного цеоліту СaA, $\mathrm{CaE}-\mathrm{H}$, карбонізованого викопного вугілля, промислового активного вугілля типу СКТ-2А, СКТ-4Б, вуглецевих волокнистих матеріалах типу КУТ та ін.) у діапазоні тисків $10^{-9} \ldots 10^{-3}$ мм рт. ст. і температур 20,7 ..27,0...78 K.

Разом із колегами розвинув новий напрям в адсорбційній науці - кріовакуумна активована фізична адсорбція; виявив ії механізм і закономірності, розробив методи використання для вивчення мікропористої структури адсорбентів, практичні рекомендації для використання у кріовакуумних пристроях, які проектували та зводили в той час на низці підприємств, зокрема п/с В-2572, п/с A-3605, «Єлектроважмаш», «Завод транспортного обладнання», ВО «Енергія». 1974 року захистив кандидатську дисертацію «Исследование криовакуумной адсорбции компонентов воздуха углеродными адсорбентами с различной пористой структурой» і того ж року отримав диплом кандидата фізико-математичних наук (МФМ № 022867). Відтоді фактично керував групою молодших наукових співробітників лабораторії № 15-20.

Від 1983 до 1986 року був молодшим науковим співробітником, старшим науковим співробітником, начальником наукової групи перспективного планування, прогнозування науково-дослідної роботи та удосконалення системи управління науковими дослідженнями науково-технічного відділу (№ 86-00); у 1986-1994 роки - начальником лабораторії наукової організації праці та управління виробництвом (№ 42-00); від 1994 року - 
старшим науковим співробітником відділу патентів і науково-технічної інформації (№ 87-00).

Від початку 1990-х до 2011 року займався науково-методичним, науково-організаційним та інформаційним забезпеченням у фізико-технічній галузі та ХФТІ у зв’язку з конверсією, розвитком робіт з атомної науки і техніки, перетворенням галузевого збірника «Вопросы атомной науки и техники» в український науковий журнал, атестацією науково-технічного потенціалу ХФТІ. За весь період наукової та науково-організаційної діяльності самостійно та разом з колегами написав понад 80 наукових статей і оглядів, запатентував 3 винаходи, був виконавцем, співкерівником і керівником понад 25 наукових та науково-організаційних тем фундаментального і прикладного характеру.

За словами колег з ХФТІ, Костянтин Георгійович мав такі якості, як високий професіоналізм, широкий діапазон інтересів, творча активність і відповідальність за доручену справу, комунікабельність, дисциплінованість, старанність, чуйність, сприйнятливість до критики, як від керівництва, так і від товаришів по роботі. Він завжди із задоволенням ділився своїми знаннями зі всіма, хто до нього звертався. 3 великою повагою ставився до рідного Інституту, чудово знав його історію, поважав започатковані в ньому традиції, щорічно з великим ентузіазмом супроводжував нові інститутські експонати на різноманітні виставки.

П’ять років тому (19 квітня 2012) на 71-му році життя після тривалої та тяжкої хвороби Костянтин Бреславець відійшов у засвіти. Маючи твердий характер і сильні вольові якості, які змалку неодноразово допомагали досягати поставленої мети та долати труднощі, понад два останніх роки він боровся за життя, а його родина, друзі та колеги всіляко підтримували його і сподівалися на диво. Хвороба повністю прикувала Костянтина Георгійовича до ліжка, однак не змогла здолати його духовно. Він не лише був хорошим науковцем, вірним товаришем і добрим сім'янином (разом зі своєю однокласницею, дружиною та другом Лорою Олександрівною виховав сина Юрія та доньку Карину, встиг дочекатися внуків Олександра та Михайла), а й патріотом України. На його могилі на плиті викарбували рядки з улюбленої пісні «У райськім саду (Яворина)» (слова С. Галябарди, композитор і виконавець С. Гіґа):

... Я любив Вас усіх, та найбільше любив Україну,

Певно, в цьому і $є$ та найважча провина моя.

Українська наука і техніка, енциклопедистика зазнали значних втрат, але тішить те, що, за словами дружини, Костянтин Георгійович пішов в інший світ щасливою людиною, бо присвятив своє життя улюбленій справі, зробив багато доброго та корисного, користувався великою повагою колег і близьких, загалом прожив насичене та цікаве життя. 


\title{
KOSTIANTYN HEORHIYOVYCH BRESLAVETS (1941-2012)
}

\author{
Anatolii Shushkivskyi \\ NASU Institute of Encyclopedic Resarch, \\ Kyiv, Ukraine
}

This personological study is devoted to Kostiantyn Breslavets as an author and coordinator of the Encyclopedia of Modern Ukraine, candidate in Physics and Mathematics.

Keywords: Kostiantyn Breslavets, Encyclopedia of Modern Ukraine, Kharkiv Institute of Physics and Technology, Kharkiv. 